\title{
A phytosociological analysis and synopsis of the dry woodlands and succulent vegetation of the Peruvian Andes
}

\author{
ANTONIO GALÁN-DE-MERA ${ }^{1}$, ISIDORO SÁNCHEZ-VEGA ${ }^{2}$, ELIANA LINARES-PEREA ${ }^{3}$, \\ JOSÉ CAMPOS ${ }^{4}$, JUAN MONTOYA ${ }^{2}$ and JOSÉ A. VICENTE-ORELLANA ${ }^{1}$

\begin{abstract}
${ }^{1}$ Laboratorio de Botánica, Universidad CEU San Pablo, Apartado 67, 28660 Boadilla del Monte, Madrid, España ${ }^{2}$ Laboratorio de Botánica, Universidad Privada Antonio Guillermo Urrelo (UPAGU), Jr. José Sabogal 913, Cajamarca, Perú ${ }^{3}$ Estudios Fitogeográficos del Perú, Sánchez Cerro 219, Manuel Prado, Paucarpata, Arequipa, Perú ${ }^{4}$ Museo de Historia Natural, Universidad Nacional Mayor de San Marcos, Apartado 140434, Lima, Perú
\end{abstract}

Manuscript received on May 18, 2015; accepted for publication on July 14, 2015

\begin{abstract}
A phytosociological approach to dry forest and cactus communities on the occidental slopes of the Peruvian Andes is presented in base of 164 plots carried out following the Braun-Blanquet method. From them, 52 have been made recently, and the other 112 were taken from the literature. After a multivariate analysis, using a hierarchical clustering and a detendred correspondence analysis, the Acacio-Prosopidetea class (dry forest and cactus communities, developed on soils with some edaphic humidity or precipitations derived from El Niño Current), the Opuntietea sphaericae class (cactus communities of central and southern Peru, on few stabilized rocky or sandy soils) and the Carico-Caesalpinietea class (dry forests of the Peruvian coastal desert, influenced by the maritime humidity of the cold Humboldt Current), are differentiated. Within the Acacio-Prosopidetea class, two alliances are commented: the Bursero-Prosopidion pallidae (with two new associations Loxopterygio huasanginis-Neoraimondietum arequipensis and Crotono ruiziani-Acacietum macracanthae), and the new alliance Baccharido-Jacarandion acutifoliae (with the new associations Armatocereo balsasensis-Cercidietum praecocis and Diplopterydo leiocarpae-Acacietum macracanthae). For the Opuntietea sphaericae class, the association Haageocereo versicoloris-Armatocereetum proceri (Espostoo-Neoraimondion) is described on the basis of plots from hyperarid localities of central Peru. Finally, a typological classification of the studied plant communities is given.
\end{abstract}

Key words: Acacio-Prosopidetea, cactus communities, dry forests, Opuntietea sphaericae, Peru, Phytosociology.

\section{INTRODUCTION}

Dry forests and cactus communities are widely extended in South America (Blanco et al. 2013). In Peru, they are concentrated on the western slopes of the Andean Cordillera, in the inter-Andean valleys,

Correspondence to: José Alfredo Vicente-Orellana

E-mail: avicore@ceu.es and in the north of the country (Linares-Palomino et al. 2003). There, in the north, dry forests are further extended as a continuation of the Ecuadorian dry forests (Aguirre et al. 2006). These plant formations in Peru, with rainfall less than $500 \mathrm{~mm} /$ year, are linked to the uplift of the Andean Cordillera in the Paleocene, and the strengthening of the cold 
Humboldt Current in the Eocene (Livermore et al. 2005), evolving a hyperarid period in the Atacama Desert (Luebert and Gajardo 2005) which isolated some territories with a large number of endemic plants (Galán de Mera et al. 1997).

The floristic characterizations of Weberbauer (1945) and Ferreyra (1960, 1983), and recent studies on the dry deciduous forests of northern Peru, were analysed by comparing their structure and floristic relationships, with preference of a pool of woody species (Phillips and Miller 2002, Bridgewater et al. 2003, Linares-Palomino et al. 2003, LinaresPalomino 2004a, b, Linares-Palomino and Ponce Alvarez 2005). Regarding the cactus communities of Peru, some phytosociological data (Galán de Mera and Vicente Orellana 1996, Galán de Mera and Gómez Carrión 2001, Galán de Mera et al. 2002a, b, 2004, 2009, Galán de Mera and Linares Perea 2012, Montesinos et al. 2012) are known, as well as the plant systematic bibliography with geographical information (Rauh 1958, Ritter 1981, Hunt 2006).

The Peruvian endemic cactus occur also within northern dry forests around the AmotapeHuancabamba Zone (Weigend 2002), and the occidental Andean slopes and inter-Andean valleys, contributing to the original plant communities of this country. Thus, a new phytosociological contribution along the Peruvian Andes is reported in this paper, with the aim to understand better the beta-diversity of these dry plant communities throughout the syntaxonomical units.

\section{MATERIALS AND METHODS}

STUDY AREA

The studied area covers circa $1600 \mathrm{Km}$ along the occidental slopes of the Peruvian Andes up to $3000 \mathrm{~m}$ asl, where vegetation changes from succulent vegetation to the Andean shrublands. We have taken data from the southern Peruvian border in the Tacna Department (approximate latitude- $18^{\circ} 01^{\prime} \mathrm{S}-70^{\circ} 14^{\prime} \mathrm{W}$ ) to North Peru in the Cajamarca Department (approximate latitude$\left.07^{\circ} 16^{\prime} \mathrm{S}-79^{\circ} 08^{\prime} \mathrm{W}\right)$. In the Cajamarca Department, the succulent vegetation around the Huancabamba Depression $\left(06^{\circ} 03^{\prime} \mathrm{S}-79^{\circ} 04^{\prime} \mathrm{W}\right)$ and in the Marañón valley (between $06^{\circ} 35^{\prime} \mathrm{S}-7^{\circ} 06^{\circ} \mathrm{W}$ and $05^{\circ} 45^{\prime} \mathrm{S}-78^{\circ} 41^{\prime} \mathrm{W}$ ) were also investigated as well the wide coast of the Arequipa Department in southern Peru (approximate latitude- $17^{\circ} 02^{\prime} \mathrm{S}-71^{\circ} 43^{\prime} \mathrm{W}$ ).

The tropical climate in all the studied localities is arid $(0-300 \mathrm{~mm})$ to dry $(300-500 \mathrm{~mm})$, except for some sites of the northern, where annual precipitation can reach $900 \mathrm{~mm}$. The annual average temperatures oscillate between $15^{\circ} \mathrm{C}$ to $25^{\circ} \mathrm{C}$. For a bioclimatic diagnosis of Peruvian syntaxa, the bioclimatic model of Rivas-Martínez is followed (Rivas-Martínez and Rivas-Saenz 1996-2009), where data from meteorological stations between infra- and supratropical belts with hyperarid to dry precipitation range, have been considered. For its intervals and nomenclature see Table I.

TABLE I

Bioclimatic belts and interval types of precipitation according to the bioclimatic model of Rivas-Martínez. It $=10(\mathrm{~T}+\mathbf{m}+\mathrm{M})\left[\mathrm{T}\right.$ : average annual temperature $\left(\right.$ in $\left.{ }^{\circ} \mathrm{C}\right)$, $\mathrm{m}$ : average lowest temperature in the coldest month, $\mathrm{M}$ : average highest temperature in the coldest month], P: annual precipitation.

\begin{tabular}{|c|c|c|c|}
\hline \multicolumn{2}{|c|}{ Bioclimatic belts } & \multicolumn{2}{l|}{ Interval types of precipitation } \\
\hline & It & & $\mathrm{P}(\mathrm{mm})$ \\
\hline Infratropical & $>610$ & Ultrahyperarid & $<5$ \\
\hline Thermotropical & $610-471$ & Hyperarid & $5-30$ \\
\hline Mesotropical & $470-311$ & Arid & $30-100$ \\
\hline Supratropical & $310-171$ & Semiarid & $100-300$ \\
\hline \multirow{2}{*}{} & Dry & $300-500$ \\
\cline { 3 - 4 } & & Subhumid & $500-900$ \\
\cline { 2 - 4 } & &
\end{tabular}

Except the sedimentary geologic materials linked to the rivers, the sea, and Aeolian deposits, the occidental slopes of the southern Peruvian Andes present a volcanic origin (Instituto de Geología y Minería 1975). From the Arequipa Department 
to the South, the landscape is characterized by a sequence of volcanoes that reach approximately $6000 \mathrm{~m}$ asl (i.e. Ampato, Coropuna and Hualca Hualca). Central and northern Peru present specially metamorphic outcrops, as granites and diorites, as we can observe in the Huascarán (6768 m asl), and in the Huancabamba Depression (2145 m asl), the low zone of the tropical Andes, and where the central Andes and the northern Andes diverge between a landscape of dry forests. Dry forests and succulent plant communities of northern Peru are influenced by the rainfall originating from the warm maritime El Niño Current, while the cactus communities below $8^{\circ} \mathrm{S}$ indicate an arid climate originating from the rain shadow derived of the altitude of the Andes and the anticyclone situation produced by the cold maritime Humboldt Current.

\section{STUDYING THE VEGETATION}

A phytosociological study of northern dry forests and cactus communities of the occidental slopes of Peruvian Andes, including some localities of the coastal desert, is presented. It is based on 164 plots carried out following the Braun-Blanquet method (Braun-Blanquet 1979, Biondi 2011). Fifty-two of them have been made recently by the authors, and the rest have been taken from numerous references from other authors. A synthetic table was made up with all the plots (Table SII - Supplementary Material) using SORT 4.1 program (Ackermann and Durka 1997), where percentage intervals of species presence were transformed into symbols $(<10 \%=$ ,+ 11 to $20 \%=1,21$ to $40 \%=2,41$ to $60 \%=3$, 61 to $80 \%=4$, and $>81 \%=5$ ); their references are given in the Appendix I. Table SIII (Supplementary Material) shows the plots of the new associations and alliances; their localities are presented in the Appendix II.

In order to improve the manual classification of the columns of Table SII, a hierarchical clustering producing a dendrogram has been made, using the similarity index (UPGMA) of Bray and Curtis (1957), which takes into account the abundance values of the plants of the plots. A detrended correspondence analysis (DCA) is provided in order to discuss how columns are grouped. This statistical analysis was performed by PAST 3.04 program (Hammer 2014).

To discuss the higher phytosociological units and their relationships with the vegetation neighboring Peru, some works from Ecuador (Aguirre et al. 2006, Weigend 2002, 2004), Colombia (Rangel et al. 1997, Ruiz et al. 2002) and Chile (Luebert and Gajardo 2005), have been consulted. As a result, some new associations and other phytosociological units are described.

The nomenclature of taxa in the text and tables follows The Plant List (2013). For the nomenclature of syntaxonomical units, the International Code of Phytosociological Nomenclature is followed (Weber et al. 2000).

\section{RESULTS}

\section{STATISTICAL ANALYSIS}

The dendrogram of Figure 1 and Table SII show the variability of dry forests and cactus communities in the Andean occidental slopes, the Marañón valley and some localities of the coastal desert. Four branches are clearly differentiated in the dendrogram: Opuntietea class (branch A, columns 8 to 24) -cactus communities of central and southern Peru-, Acacio-Prosopidetea class (branch B, columns 6 to 2) -dry forests and cactus communities of northern Peru-, and the desert forests of CaricoCaesalpinietea class (branch C, columns 29 to 31) (Galán de Mera and Vicente Orellana 1996, Galán de Mera et al. 2009). Column 32 (branch D) is the most separated from them, belonging to the Echinopsio schoenii-Proustietea cuneifoliae class (Montesinos et al. 2012).

The DCA of Figure 2 shows isolated plant groups (A-H) within each phytosociological 


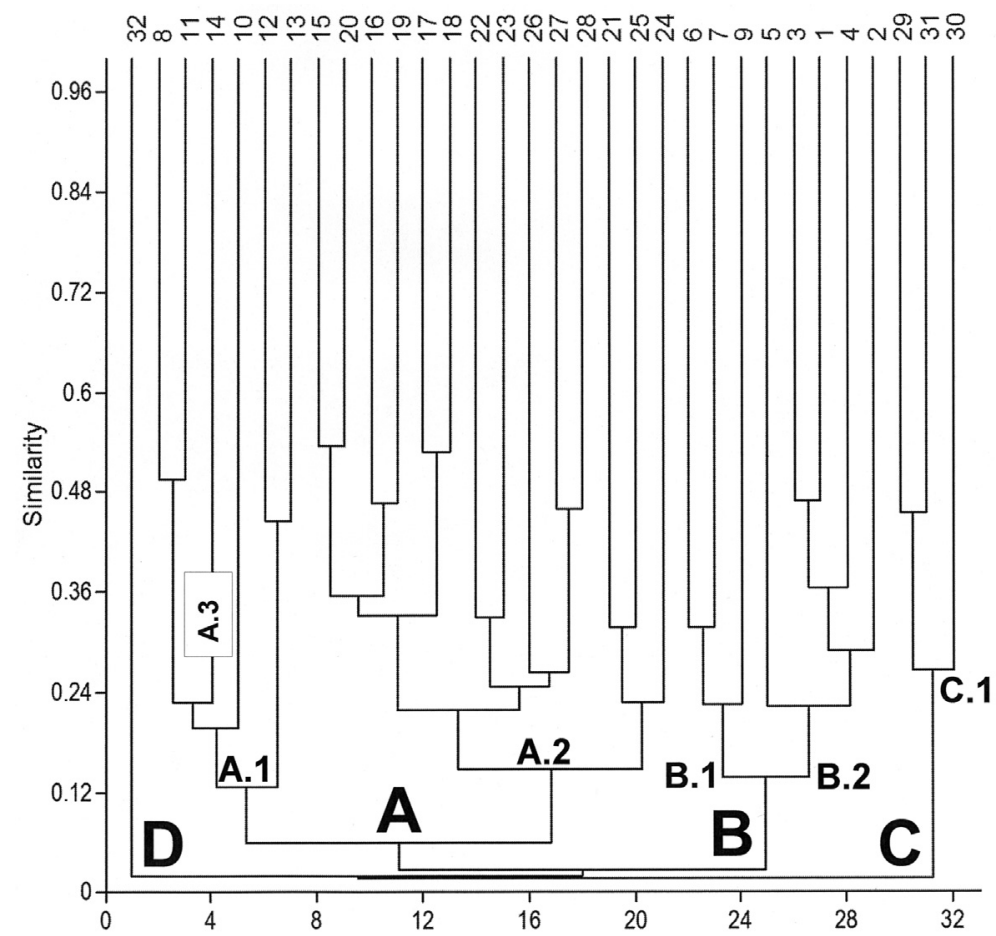

Figure 1 - Dendrogram with the studied phytosociological classes and their alliances. (A) Opuntietea sphaericae: (A.1) Espostoo-Neoraimondion, (A.2) Corryocaction brevistyli, and (A.3) Haageocerion procumbentis. (B) AcacioProsopidetea: (B.1) Bursero-Prosopidion pallidae and (B.2) BaccharidoJacarandion acutifoliae. (C) Carico-Prosopidetea with the Gridelion glutinosae alliance, (D) Anredero diffusae-Diplostephietum meyenii association (Echinopsio-Proustietea class). The reference numbers of the branches are indicated in the Appendix I.

class: A- Caesalpinia spinosa, Carica candicans, Croton alnifolius, Citharexylum flexuosum, Heliotropium arborescens, Randia rotundifolia, Senecio mollendoensis, and Stipa pachypus; BAlternanthera porrigens, Armatocereus rauhii subsp. balsasensis, Baccharis oblongifolia, Cyathostegia weberbaueri, Dalea carthagenensis, Diplopterys leiocarpa, Dodonaea viscosa, Jacaranda acutifolia, Lantana camara, Matucana celendinensis, Melinis repens, Pappobolus acutifolia, and Puya mima; C-Bursera graveolens, Capparicordis crotonoides, Loxopterygium huasango, Deuterocohnia longipetala, and Onoseris odorata; D- Espostoa melanostele, Mila nealeana, Orthopterygium huaucui, Pluchea chingoyo, and Weberbauerocereus johnsonii; E-
Corryocactus brachypetalus, Eriosyce islayensis, and Haageocereus decumbens; F and G- Ambrosia artemisioides, Armatocereus riomajensis, Austrocylindropuntia subulata, Balbisia meyeniana, Browningia candelaris, Corryocactus aureus, C. brevistylus, Cylindropuntia tunicata, Euphorbia apurimacensis, Gochnatia arequipensis, Haageocereus platinospinus, Lantana scabiosiflora, Oreocereus hempelianus, Weberbauerocereus rauhii, and $W$. weberbaueri; $\mathrm{H}$ - Anredera diffusa, Bomarea ovata, Bowlesia sodiroana, Cumulopuntia corotilla, Cylindropuntia rosea, Diplostephium meyenii, Dunalia spinosa, Echinopsis schoenii, Fuertesimalva echinata, Heliotropium microstachyum, Jaegeria hirta, Lophopappus foliosus, Mirabilis expansa, 
Mostacillastrum gracile, Mulguraea arequipensis, Mutisia acuminata, Neowerdermannia peruviana, Oxalis megalorrhiza, Philibertia solanoides, Proustia cuneifolia, Portulaca pilosa, Salvia oppositiflora, Senecio tovarii, and Viguiera lanceolata. $\mathrm{F}$ is separated from $\mathrm{G}$ by the presence of Neoraimondia arequipensis in the plots.

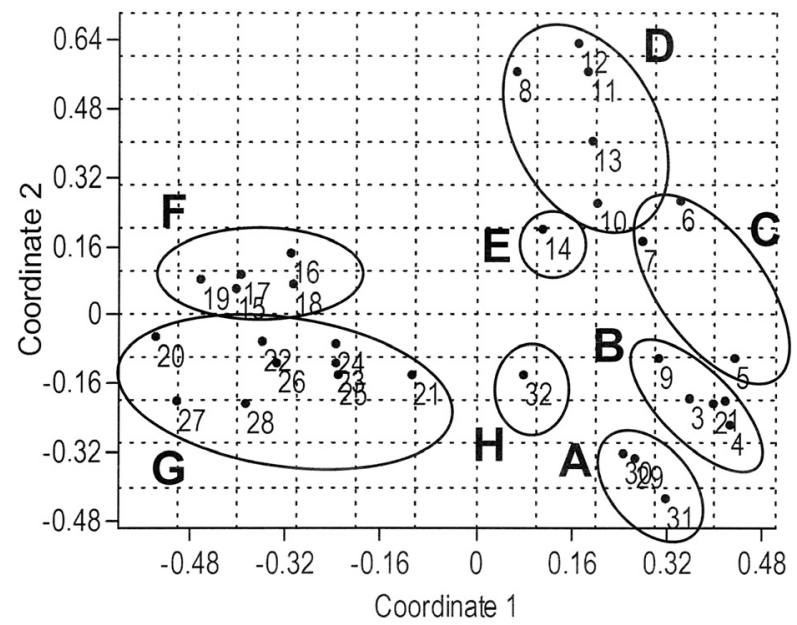

Figure 2 - DCA with the alliances of the Opuntietea sphaericae, Acacio-Prosopidetea, and Carico-Caesalpinietea classes. (A) Grindelion glutinosae, (B) Baccharido-Jacarandion acutifoliae, (C) Bursero-Prosopidion pallidae, (D) Espostoo-Neoraimondion, (E) Haageocerion procumbentis, (F) thermotropical version of Corryocaction brevistyli, (G) mesotropical version of Corryocaction brevistyli, (H) Anredero diffusaeDiplostephietum meyenii association (Echinopsio-Proustietea class). The reference numbers are indicated in the Appendix I.

Figure 3 shows the distribution of Acacio-Prosopidetea and Opuntietea classes in Peru. The first class is distributed in the north, while the second is widely distributed in central and southern Peru.

\section{ALLIANCES AND THEIR ASSOCIATIONS}

The Acacio-Prosopidetea class encloses the dry forests and succulent plant communities of northern Peru, influenced by the rainfall originating from the warm El Niño Current, and also forests on riverside humid soils of the Western Andes, between 100 and $2500 \mathrm{~m}$ asl (Galán de Mera et al. 2009).

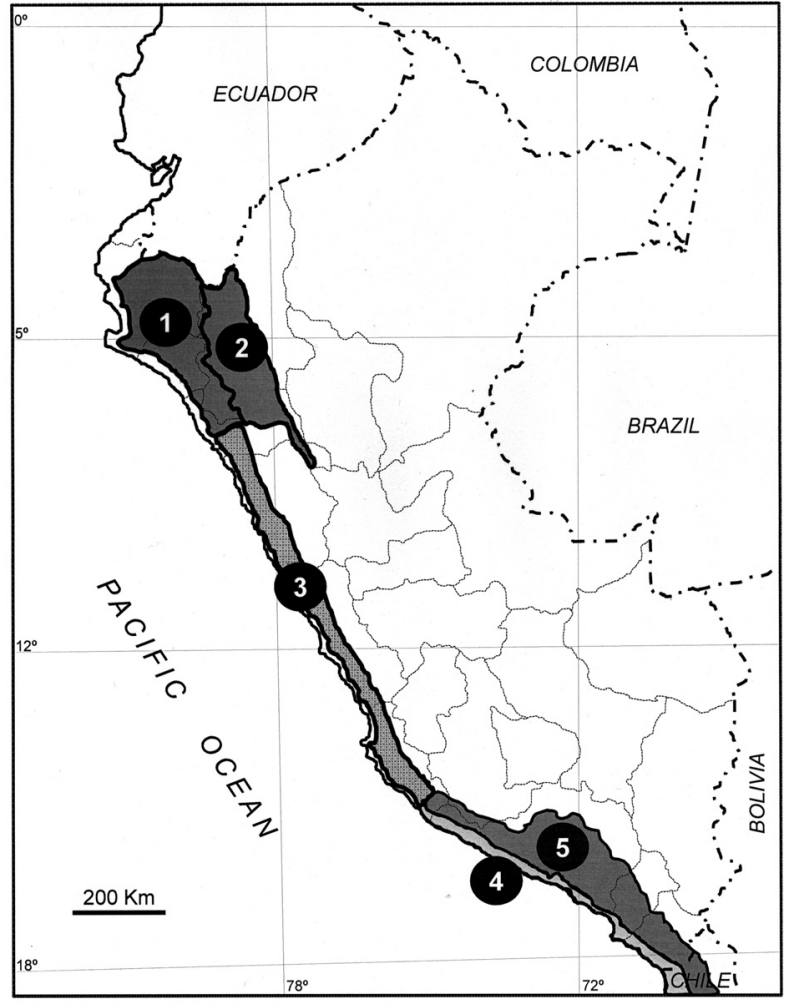

Figure 3 - Distribution of the alliances of the AcacioProsopidetea class -(1) Bursero-Prosopidion pallidae, and (2) Baccharido-Jacarandion acutifoliae-, and Opuntietea sphaericae class -(3) Espostoo-Neoraimondion, (4) Haageocerion procumbentis, and (5) Corryocaction brevistyli in Peru.

Cryptocarpo-Prosopidetalia shows two groups in the dendrogram (Fig. 1, branches 6 to 9, and 5 to 2) and also in the DCA (Fig. 2, groups B and C), which in Table SII are interpreted as the two phytosociological alliances, Bursero-Prosopidion pallidae (columns 6 to 5) and BaccharidoJacarandion acutifoliae (columns 9 to 2).

Bursero-Prosopidion pallidae (Galán de Mera et al. 2002a) are the infratropical and thermotropical semiarid associations [Table SII: Loxopterygio huasanginis-Neoraimondietum arequipensis (column 6), Cercidio praecocis-Prosopidetum pallidae (column 7), and Crotono ruizianiAcacietum macracanthae (column 5)], throughout the occidental slopes of the Andes between 100 and $2500 \mathrm{~m}$ (Fig. 3.1). The characteristic species of 
the alliance are Bougainvillea peruviana, Bursera graveolens, Capparicordis crotonoides, Cordia lutea, Croton lobatus, Deuterocohnia longipetala, Loxopterygium huasango, Onoseris odorata, and Prosopis pallida, according to the altitudinal distribution indicated by Ceroni Stuva (2003). In a recent work (Galán de Mera et al. 2013), the subhumid forests of the Annono cherimolaeAcacietum macracanthae association is mentioned between $2000-2500 \mathrm{~m}$ asl, but it is a very disturbed forest where we could not find plots of sufficient homogeneity.

Baccharido oblongifoliae-Jacarandion acutifoliae all. nova hoc loco (holotypus: Diplopterydo leiocarpae-Acacietum macracanthae ass. nova; characteristic species: Alternanthera porrigens, Anadenanthera colubrina var. cebil, Armatocereus rauhii subsp. balsasensis, Baccharis oblongifolia, Bauhinia glabra, Browningia altissima, Cedrela kuelapensis, Ceiba insignis, Celtis loxensis, Clusia pavonii, Cordia macrocephala, C. saccellia, Croton adipatus, C. thurifer, Cyathostegia weberbaueri, Dalea carthagenensis, Diplopterys leiocarpa, Dodonaea viscosa, Durantha triacantha, Ditassa endoleuca, Esenbeckia warszewiczii, Ferreyranthus verbascifolius, Flourensia cajabambensis, Geoffroea spinosa, Jacaranda acutifolia, Kageneckia lanceolata, Lantana camara, L. haughtii, Leucaena trichodes, Matucana celendinensis, Melinis repens, Melocactus bellavistensis, Mimosa incarum, M. pectinatipinna, Opuntia quitensis, Pappobolus acutifolia, P. hutchisonii, Pappophorum pappiferum, Pereskia horrida, Puya mima, Salvia loxensis, Salvia psilostachya, Senna galegifolia, Tecoma rosifolia, and Trixis subparadoxa), is a new alliance represented by thermotropical dry-subhumid forests and succulent vegetation, with a canopy of 10-12 m, which extends between the Marañón Basin and the low altitudes in the surroundings of the Huancabamba Depression, between 1500$2500 \mathrm{~m}$ asl (Fig. 3.2) [Table SII: Diplopterydo
leiocarpae-Acacietum macracanthae (columns 3 to 2); Table SIII, plots 28 to 43].

Opuntietea sphaericae class includes the cactus plant communities of central and southwestern Peru, and Chile, up $3000 \mathrm{~m}$ asl, on few stabilized rocky, or sandy soils (Fig. 3). Thus the concept of their distribution throughout South America has been amended, since the original description of Galán de Mera and Vicente Orellana (1996) that proposed a distribution throughout the Neotropics. Its Oreocereo-Neoraimondietalia order includes three alliances with a clear geographic distribution up to $3000 \mathrm{~m}$ asl: Espostoo melanostelis-Neoraimondion arequipensis (Galán de Mera et al. 2002a, 2004), extended through the hyperarid and semiarid thermotropical belt of central Peru (Fig. 1, branches 8 to 13; Fig. 2, group D), between the parallel $8^{\circ} \mathrm{S}$ and Ica Department (Fig. 3.3) [characteristic species: Armatocereus procerus, Espostoa melanostele, Mila nealeana, Orthopterygium huaucui, Pluchea chingoyo, Weberbauerocereus johnsonii; associations: Table SII. Haageocereo limensis-Neoraimondietum arequipensis (column 8 and 11), subassociation with Pluchea chingoyo (column 12), subassociation with Puya ferruginea (column 13), and Haageocereo versicolorisArmatocereetum proceri (column 10)].

Haageocerion decumbentis (Ostolaza and Michles 1984, Galán de Mera et al. 2002b), represents the hyperarid cactus communities of the southern coastal desert up $250 \mathrm{~m}$ asl (Fig. 3.4) [characteristic species:Corryocactus brachypetalus, Eriosyce islayensis, and Haageocereus decumbens; associations: Table SII. Neoporterio islayensisNeoraimondietum arequipensis (column 14)]. Although Haageocerion decumbentis is a southern alliance, in the dendrogram (Fig. 1, branch 14) and also in the DCA (Fig. 2, group E), it is close to the cactus communities of central Peru with $N$. arequipensis, due to its low diversity and the absence of Corryocactus brevistylus.

Corryocactus brevistylus grows between the arid and semiarid thermotropical and supratropical 
belts, and indicates the Corryocaction brevistyli alliance from southern Peru (Fig. 1, branches 15 to 24; Fig. 2, groups F and G), between Ica and Tacna Regions (Galán de Mera and Vicente Orellana 1996, Galán de Mera et al. 2009, 2011), to northern Chile (Luebert and Gajardo 2005) (Fig. 3.5) [characteristic species: Ambrosia artemisioides, Armatocereus riomajensis, Austrocylindropuntia subulata, Balbisia meyeniana, B. verticillata, Bougainvillea spinosa, Browningia candelaris, B. viridis, Cantua volcanica, Carica augusti, Corryocactus aureus, C. brevistylus, C. puquiensis, Cylindropuntia tunicata, Echinopsis schoenii, Euphorbia apurimacensis, Gochnatia arequipenis, Grindelia tehuelches, Haageocereus platinospinus, Jatropha macrantha, Lantana scabiosiflora, Larrea divaricata, Malesherbia ardens, Mulguraea arequipensis, Oreocereus hempelianus, O. tacnaensis, Weberbaueroceres rauhii, W. torataensis, and $W$. weberbaueri; associations: Table SII. Weberbauerocereo rauhii-Browningietum candelaris (column 15), Weberbauerocereo rauhii-Corryocactetum brevistyli (column 20), Weberbauerocereo weberbaueri-Browningietum candelaris (column 16), Weberbauerocereo rauhiiBrowningietum candelaris with Larrea divaricata subassociation (column 19), Weberbauerocereo weberbaueri-Corryocactetum brevistyli (column 22), Neoraimondio arequipensis-Browningietum viridis (column 17), Armatocereo riomajensisNeoraimondietum arequipensis (column 18), Weberbauerocereo torataensis-Corryocactetum brevistyli (column 26), Corryocactus aureiBrowningietum candelaris (column 27), Oreocereo tacnaensis-Corryocactetum brevistyli (column 28), Weberbauerocereo rauhii-Corryocactetum brevistyli with Croton ruizianus subassociation (column 21), Grindelio bergii-Corryocactetum puquiensis (column 25), Armatocereo riomajensisEuphorbietum apurimacensis (column 24), and Balbisio weberbaueri-Ambrosietum artemisioidis (column 23).
Columns 29-30 of Table SII represent the low diversity of the Carico-Caesalpinietea class (characteristic species: Caesalpinia spinosa, Carica candicans, Citharexylum flexuosum, Croton alnifolius, Dicliptera tomentosa, Grindelia glutinosa, Heliotropium arborescens, Myrcianthes ferreyrae, Randia rotundifolia, Senecio mollendoensis, and Stipa pachypus), grouping thermotropical forests of Caesalpinia spinosa on the coastal mountains of central Peru, shrubs of Echinopsio chalaensis-Randietum armatae, and forests of Caesalpinio spinosae-Myrcianthetum ferreyrae in southern Peru, with a dry rain interval (Galán de Mera et al. 2009). In the dendrogram (Fig. 1, branch C), and especially in the DCA (Fig. 2), Carico-Caesalpinietea (group A) is near Bursero-Prosopidion pallidae (group B) according to the presence of some plants in common, such as Acacia macracantha, Caesalpinia spinosa, Croton ruizianus, and Trixis cacalioides.

The new associations

- Haageocereo versicoloris-Armatocereetum proceri ass. nova hoc loco (Table SIII, plots 1-6, holotypus: plot 3; characteristic species: Armatocereus procerus, and Haageocereus versicolor).

Thermotropical hyperarid column cactus communities situated between 800-1000 m asl, on plutonic Tertiary rocks, where Armatocereus procerus and Haageocereus versicolor grow on slopes with an inclination between 50 and $60 \%$. Unlike the Haageocereo limensisNeoraimondietum arequipensis, this association is situated in localities where is submitted to a higher maritime influence.

- Loxopterygio huasanginis-Neoraimondietum arequipensis ass. nova hoc loco (Table SIII, plots 7-12, holotypus: plot 10; characteristic species: Capparicordis crotonoides, Cnidoscolus basiacanthus, Heliotropium ferreyrae, 
Loxopterygium huasango, and Neoraimondia arequipensis).

Infratropical arid-semiarid cactus community with Neoraimondia arequipensis and Haageocereus versicolor, enriched with small trees such as Bursera graveolens, Cercidium praecox, and Loxopterygium huasango, extending between $5^{\circ} \mathrm{S}$ and $8^{\circ} \mathrm{S}$, with different inclinations up to $60 \%$, from the surroundings of Sullana (Piura) to the North of Trujillo (La Libertad). The geological materials where it is placed are Cretaceous volcanic sedimentary soils, and Tertiary volcanic and plutonic rocks.

- Crotono ruiziani-Acacietum macracanthae ass. nova hoc loco (Table SIII, plots 13-15, holotypus: plot 14; characteristic species: Croton ruizianus, and Verbesina sp.).

Thermotropical dry forest where Croton ruizianus reaches its highest abundance on the occidental slopes of the Andes, between 1000 and $2000 \mathrm{~m}$ asl, accompanied by Alternanthera halimifolia, Bursera graveolens, Ipomoea incarnata, and Ruellia floribunda, and marking the difference with respect to the associations of the alliance Baccharido-Jacarandion acutifoliae occurring in the Marañón River system.

The plots of this association have been sampled in some localities to the South of the Cajamarca Department on Cretaceous volcanic sedimentary and Tertiary plutonic soils with heavy clay substrata.

- Armatocereo balsasensis-Cercidietum praecocis ass. nova hoc loco (Table SIII, plots 1627, holotypus: plot 18; characteristic species: Armatocereus rauhii subsp. balsasensis, Bougainvillea peruviana, Browningia altissima, Cordia saccellia, Croton adipatus, C. thurifer, Lantana haughtii, Melocactus bellavistensis, Mimosa incarum, M. pectinatipinna, Oxalis psoraleoides, and Pereskia horrida).

Infratropical semiarid cactus community with Armatocereus rauhii subsp. balsasensis and Brown- ingia altissima with shrubs and small trees such as Bougainvillea peruviana, Cercidium praecox, Cordia saccellia, or Croton thurifer that extends throughout the Huancabamba Depression and the Marañón Valley, with an inclination up to $60 \%$. This association grows on volcanic sedimentary soils of the Jurassic and Cretaceous Ages, Tertiary volcanic and plutonic rocks, and also on recent sedimentary materials from the Marañón River.

- Diplopterydo leiocarpae-Acacietum macracanthae ass. nova hoc loco (Table SIII, plots 28-43, holotypus: plot 29; characteristic species: Anadenanthera colubrina var. cebil, Cyathostegia weberbaueri, Diplopterys leiocarpa, Leucaena trichodes, Matucana celendinensis, Pappophorum pappipherum, Puya mima, and Tecoma rosifolia).

Thermotropical dry forest characterized by elements with a concentrated distribution south of the Huancabamba Depression, between 1500 and $2500 \mathrm{~m}$ asl, where Cedrela kuelapensis, Diplopterys leiocarpa, Flourensia cajabambensis, Matucana celendinensis, Pappobolus hutchisonii, Salvia psilostachya and Tecoma rosifolia are endemic plants. This association grows on clay soils proceeding from Cretaceous volcanic sedimentary rocks with a maritime or continental origin.

The highest areas (2300-2500 m asl) of this association are enriched with Flourensia cajabambensis, Ferreyranthus verbascifolius, and Salvia loxensis, and can be described as Diplopterydo leiocarpae-Acacietum macracanthae flourensietosum cajabambensis subass. nova (Table SIII, plots 35-38, holotypus: plot 38; characteristic species: Ferreyranthus verbascifolius, Flourensia cajabambensis, and Salvia loxensis). On the other hand, the subassociation Diplopterydo leiocarpae-Acacietum macracanthae clusietosum pavonii subass. nova (Table SIII, plots 39-43, holotypus: plot 43; characteristic species: Cedrela kuelapensis, Ceiba insignis, Celtis loxensis, Clusia pavonii, Esenbeckia warszewiczii, Pappobolus 
hutchisonii, Peperomia glabella, Salvia cuspidata, and $S$. psilostachya), is present in the lowest part of the Yangas Valley (1500-1800 m asl), with very frequent fogs.

\section{DISCUSSION}

Within the Opuntietea class, southern Peru presents a high beta-diversity in terms of associations (Whittaker 1972), stimulated by the important influence of the cold Humboldt Current, coupled with the western rain shadow caused by the elevation of the Peru-Bolivia Altiplano $(\sim 4500$ $\mathrm{m}$ asl) (Galán de Mera et al. 2012). According to the investigations of Schwarzer et al. (2010), the diversity of this territory is also a consequence of successive volcanic events. An example of this high diversity is that the Corryocaction brevistyli alliance is represented in the DCA (Fig. 2) by the separated groups $\mathrm{F}$ and $\mathrm{G}$, where $\mathrm{F}$ shows the thermotropical associations with Neoraimondia arequipensis, and $\mathrm{G}$ are the meso- and supratropical ones. However, in the Espostoo-Neoraimondion alliance, only the thermotropical associations are found.

The Anredero diffusae-Diplostephietum meyenii association (Table SII, column 32) described by Montesinos et al. (2012) in Moquegua is isolated, both in the dendrogram (Fig. 1, branch 32) and in the DCA (Fig. 2, group H). It involves plants of Oreocereo-Neoraimondietalia order (Austrocylindropuntia subulata, Echinopsis schoenii, Ephedra americana, Gochnatia arequipensis, Mulguraea arequipensis, and Oreocereus leucotrichus). However, the presence of Dunalia spinosa, Mutisia acuminata, Philibertia solanoides, Proustia cuneifolia, Salvia oppositiflora, and Viguiera lanceolata shows a mixture of Opuntietea sphaericae and Baccharidetea latifoliae communities (see Galán de Mera et al. 2011).

Peruvian dry forest communities arefloristically and ecologically linked to those of the Caribbean Region and the north of southern America. Borhidi (1991) described the Cercidio-Prosopidetea class in Cuba, where Cercidium praecox, Prosopis juliflora (also reported for Peru), and different species of Capparis and Melocactus, are present. In Colombia, forests and cactus communities with Browningia, Capparis, Melocactus, Pereskia, and Prosopis juliflora can also be found (Ruiz et al. 2002, Fernández Alonso 2006, Rangel 2012). To the South, Acacia macracantha, Annona cherimola, Espostoa lanata, Loxopterygium huasango, Prosopis pallida, Schinus molle, and others are present in Ecuador (Aguirre and Delgado 2001, Aguirre et al. 2006), belonging to the AcacioProsopidetea class (Galán de Mera et al. 2002a). However, on the western slopes of the Peruvian Andes and the coastal desert, dry forest and cactus communities with climate dependence, show some plants which support the originality of this type of vegetation with respect to those of Ecuador (Croton ruizianus, Encelia canescens, Krameria lappacea, Lycianthes lycioides, Melocactus peruvianus, Neoraimondia arequipensis, Trixis cacalioides, and Waltheria ovata). A particular phytogeographical element is Neoraimondia arequipensis, an endemic plant of Peru, which is distributed from Tacna to La Brea in Piura (Svenson 1946, Ostolaza 2011), within the Amotape-Huancabamba Zone (Weigend 2002). Acacio-Prosopidetea, with CryptocarpoProsopidetalia order (Galán de Mera et al. 2002a), encloses the dry forests that stretch to the occidental slopes of the Andes in Piura to $8^{\circ} \mathrm{S}$, in the surroundings of Trujillo, and coincide with the southern part of the Amotape-Huancabamba Zone (Weigend 2002).

Armatocereo balsasensis-Cercidietum praecocis (Table SII, column 9; Table SIII, plots 16 to 27), represented in the dendrogram as a separated association from those of Bursero-Prosopidion pallidae, really belongs to the Baccharido-Jacarandion acutifoliae alliance (see Fig. 2, group B), because it is an oriental association distributed through the Marañón Valley and the Huancabamba Depression. Among its floristic components, several occidental plants, such as Bursera graveolens, 
Loxopterygium huasango, Capparis crotonoides, and specially Neoraimondia arequipensis are absent. In the same way, Crotonoruiziani-Acacietum macracanthae (Table SII, column 5), includes occidental plants such as Bursera graveolens, Croton ruizianus, or Deuterocohnia longipetala, belonging to the Bursero-Prosopidion pallidae alliance (Fig. 2 , group $C$ ). Both alliances are also present in Ecuador (Aguirre et al. 2006), even a large number of plants, such as Cedrela kuelapensis, Cyathostegia weberbaueri, Deuterocohnia longipetala, Diplopterys leiocarpa, Flourensia cajabambensis, Matucana celendinensis, Neoraimondia arequipensis, Onoseris odorata, Pappobolus acutifolia, P. hutchinsonii, Puya mima, Salvia psilostachya, and Tecoma rosifolia, are missing from this territory (Jørgensen and León-Yáñez 1999), which characterize the associations within this alliance.

In general, dry forests can be found on deep soils along the Peruvian territory. These forests are replaced by succulent plant communities on rocky or sandy slopes $( \pm 60 \%)$, or few stabilized soils. Independently of geomorphological aspects, the Acacio-Prosopidetea class extends from the $8^{\circ} \mathrm{S}$ parallel through northern Peru (Fig. 3), linked to the influence of the warm El Niño Current (50-900 $\mathrm{mm} /$ year). Even so, in the center and south of Peru it is also placed on soils with edaphic humidity which were suitable for crops from ancient times, but without cactus (Beresford-Jones 2009). Below the $8^{\circ} \mathrm{S}$ parallel, this class is substituted by several associations of the Opuntietea sphaericae class, which tolerate higher aridity $(5-100 \mathrm{~mm} / \mathrm{year})$ and are influenced by the cold Humboldt Current. The forests and bushes of the Carico-Caesalpinietea class are marginal, being located in those places of the coastal desert with higher humidity (300-500 $\mathrm{mm} /$ year).

\section{CONCLUSIONS}

The hierarchical classification of dry forest and succulent plant communities studied, resulted in the following syntaxonomical scheme of the Opuntietea, Acacio-Prosopidetea and Carico-Caesalpinietea classes in Peru. This scheme includes the proposal of two new alliances, five associations and two subassociations.

\section{SYNTAXONOMICAL SCHEME}

OPUNTIETEA SPHAERICAE Galán de Mera and Vicente Orellana 1996

+ Oreocereo leucotrichi-Neoraimondietalia arequipensis Galán de Mera and Vicente Orellana 1996

* Espostoo melanostelis-Neoraimondion arequipensis Galán de Mera and Rosa in Galán de Mera, Rosa and Cáceres 2002

Haageocereo limensis-Neoraimondietum arequipensis Galán de Mera and Rosa in Galán de Mera, Rosa and Cáceres 2002 (neoraimondietosum arequipensis, plucheetosum chingoyonis Galán de Mera, Baldeón, Beltrán, Benavente and Gómez 2004, puyetosum ferrugineae Galán de Mera, Baldeón, Beltrán, Benavente and Gómez 2004)

Haageocereo versicoloris-Armatocereetum proceri Galán de Mera, Sánchez Vega, Linares, Campos, Montoya and Vicente ass. nova hoc loco

* Haageocerion procumbentis Galán de Mera, Cáceres and González 2002

Neoporterio islayensis-Neoraimondietum arequipensis Galán de Mera, Cáceres and González 2002

* Corryocaction brevistyli Galán de Mera and Vicente Orellana 1996

Armatocereo riomajensis-Euphorbietum apu-
rimacensis Galán de Mera, Linares, Campos
and Vicente Orellana 2009
Armatocereo riomajensis-Neoraimondietum
arequipensis Galán de Mera, Linares, Campos,
Trujillo, Villasante and Vicente Orellana 2011
Balbisio weberbaueri-Ambrosietum artemisi-
oidis Galán de Mera, Linares, Campos, Tru-
jillo, Villasante and Vicente Orellana 2011


Corryocactus aurei-Browningietum candelaris Galán de Mera and Vicente Orellana 1996 Grindelio bergii-Corryocactetum puquiensis Galán de Mera and Gómez Carrión 2001 Neoraimondio arequipensis-Browningietum viridis Galán de Mera, Linares, Campos, Trujillo, Villasante and Vicente Orellana 2011 Oreocereo tacnaensis-Corryocactetum brevistyli Galán de Mera and Vicente Orellana 1996 Weberbauerocereo rauhii-Browningietum candelaris Galán de Mera, Linares, Campos and Vicente Orellana 2009 (browningietosum candelaris, larreetosum divaricatae Galán de Mera, Linares, Campos, Trujillo, Villasante and Vicente Orellana 2011)

Weberbauerocereo rauhii-Corryocactetum brevistyli Galán de Mera, Linares, Campos and Vicente Orellana 2009 (corryocactetosum brevistyli, crotonetosum ruizani Galán de Mera, Linares, Campos and Vicente Orellana 2009)

Weberbauerocereo torataensis-Corryocactetum brevistyli Galán de Mera, Linares, Campos and Vicente Orellana 2009

Weberbauerocereo weberbaueri-Browningietum candelaris Galán de Mera and Linares Perea 2012

Weberbauerocereo weberbaueri-Corryocactetum brevistyli Galán de Mera and Gómez Carrión 2001

ACACIO MACRACANTHAE-PROSOPIDETEA PALLIDAE Galán de Mera 1999

+ Cryptocarpo pyriformis-Prosopidetalia pallidae Galán de Mera and Cáceres in Galán de Mera, Rosa and Cáceres 2002

* Bursero graevolentis-Prosopidion pallidae Galán de Mera and Cáceres in Galán de Mera, Rosa and Cáceres 2002

Cercidio praecocis-Prosopidetum pallidae Galán de Mera and Cáceres in Galán de Mera, Rosa and Cáceres 2002

Crotono ruiziani-Acacietum macracanthae

Galán de Mera, Sánchez Vega, Linares,
Campos, Montoya and Vicente ass. nova hoc loco

Loxopterygio huasanginis-Neoraimondietum arequipensis Galán de Mera, Sánchez Vega, Linares, Campos, Montoya and Vicente ass. nova hoc loco

* Baccharido oblongifoliae-Jacarandion acutifoliae Galán de Mera, Sánchez Vega, Linares, Campos, Montoya and Vicente all. nova hoc loco

Armatocereo balsasensis-Cercidietum praecocis Galán de Mera, Sánchez Vega, Linares, Campos, Montoya and Vicente ass. nova hoc loco

Diplopterydo leiocarpae-Acacietum macracanthae Galán de Mera, Sánchez Vega, Linares, Campos, Montoya and Vicente ass. nova hoc loco (acacietosum macracanthae, flourensietosum cajabambensis Galán de Mera, Sánchez Vega, Linares, Campos, Montoya and Vicente subass. nova hoc loco, clusietosum pavonii Galán de Mera, Sánchez Vega, Linares, Campos, Montoya and Vicente subass. nova hoc loco) CARICO CANDICANTIS-CAESALPINIETEA SPINOSAE Galán de Mera, Linares, Campos and Vicente Orellana 2009

+ Citharexylo flexuosi-Crotonetalia alnifolii Galán de Mera, Linares, Campos and Vicente Orellana 2009

* Grindelion glutinosae Galán de Mera, Linares, Campos and Vicente Orellana 2009

Caesalpinio spinosae-Myrcianthetum ferreyrae Galán de Mera, Linares, Campos and Vicente Orellana 2009

Caesalpinia spinosa plant community

Echinopsio chalaensis-Randietum armatae Galán de Mera, Linares, Campos and Vicente Orellana 2009

\section{ACKNOWLEDGMENTS}

This work was supported by "Mapa de vegetación de Cajamarca. Potencialidad de la vegetación 
para el uso de plantas medicinales" project of the Universidad Privada Antonio Guillermo Urrelo (Cajamarca, Peru), within the cooperation agreement with the Universidad CEU San Pablo (Madrid, Spain). Many thanks to Brian Crilly for his linguistic assistance, and also the anonymous reviewers who improved the manuscript.

\section{RESUMO}

Um método fitossociológico alternativo para a avaliação de comunidades de cactos e da floresta seca das encostas ocidentais dos Andes Peruanos é apresentado com base em 164 parcelas seguindo o método de Braun-Blanque. Destes, 52 parcelas foram obtidas recentemente, enquanto que 112 foram observadas na literatura. Após o uso de análise multivariada dos dados, seguido da aplicação de clusterização hierárquica e de uma análise de correspondência destendenciada, a classe AcacioProsopidetea (presente na floresta seca e na comunidade de cactos, crescida em solos com alguma umidade edáfica ou precipitações derivadas do Fenômeno El Niño), a classe Opuntietea sphaericae (comunidade de cactus do Peru Central e do Sul, presente em rochas estáveis ou em solos arenosos) e a classe CaricoCaesalpinietea (florestas secas do deserto costal do Peru, influenciado pela umidade marítima e pela corrente fria de Humboldt) mostraram-se diferenciadas. Dentro da classe Acacio-Prosopidetea, duas alianças são discutidas no trabalho: a aliança Bursero-Prosopidion pallidae (com duas novas associações Loxopterygio huasanginisNeoraimondietum arequipensis e Crotono ruizianiAcacietum macracanthae), bem como a nova aliança Baccharido-Jacarandion acutifoliae (com as novas associações Armatocereo balsasensis-Cercidietum praecocis e Diplopterydo leiocarpae-Acacietum macracanthae). Para a classe Opuntietea sphaericae, a associação Haageocereo versicoloris-Armatocereetum proceri (Espostoo-Neoraimondion) é descrita com base nas parcelas de localidades hiperáridas do Peru Central. Finalmente, uma classificação tipológica das comunidades de plantas estudadas é mostrada.

Palavras-chave: Acacio-Prosopidetea, comunidades de cactus, florestas secas, Opuntietea sphaericae, Peru, fitossociologia.

\section{REFERENCES}

ACKERMANN W AND DURKA W. 1997. SORT 4.1. Processing of vegetation releves and species lists. Leipzig: Edition of the authors.

Aguirre Z AND Delgado T. 2001. Vegetación de los bosques secos de Cazaderos-Mangaurco, occidente de la provincia de Loja. In: Vázquez MA, Larrea M, Suárez L and Ojeda P (Eds), Biodiversidad en los bosques secos del suroccidente de la provincia de Loja. Un reporte de las evaluaciones ecológicas y socioeconómicas rápidas. Quito: EcoCiencia, Ministerio del Ambiente, Herbario LOJA y Proyecto Bosque Seco, p. 1-15.

Aguirre Z, KVist LP AND SÁNCHEZ O. 2006. Bosques secos en Ecuador y su diversidad. In: Moraes M, Øllgaard B, Kvist LP, Borchsenius F and Balslev H (Eds), Botánica Económica en los Andes Centrales. La Paz: Universidad Mayor de San Andrés, p. 162-187.

BERESFORD-JONES DG. 2009. The role of Prosopis in ecological and landscape change in the Sacama Basin, lower Ica Valley, south coast of Peru from the early horizon to the late intermediate period. Lat Am Antiq 20(2): 303-332.

BIONDI E. 2011. Phytosociology today: Methodological and conceptual evolution. P1 Biosystems 145: 19-29.

BLANCO PD et al. 2013. A land cover map of Latin America and the Caribbean in the framework of the SERENA Project. Remote Sens Environ 132: 13-31.

BORHIDI A. 1991. Phytogeography and Vegetation Ecology of Cuba. Budapest: Akadémiai Kiadó, 858 p.

BRAUN-BlanQUeT J. 1979. Fitosociología. Madrid: H. Blume, $785 \mathrm{p}$.

BRAY JR AND CURTIS JT. 1957. An ordination of the upland forest communities of southern Wisconsin. Ecol Monogr 27: 325-349.

BRIDGEWATER S, PENNINGTON RT, RAYNEL CA, DAZA A AND PENNINGTON TD. 2003. A preliminary floristic and phytogeographic analysis of the woody flora of seasonally dry forest in northern Peru. Candollea 58: 129-148.

CERONI STUVA A. 2003. Composición florística y vegetación de la cuenca La Gallega. Morropón. Piura. Ecol Apl 2(1): 1-8.

FERNÁNDEZ ALONSO JL. 2006. Nueva especie colombiana de Browningia (Cactaceae, Cactoideae, Browningieae) potencialmente promisoria para el país. Rev Acad Colomb Cienc 30(114): 19-30.

FERREYRA R. 1960. Algunos aspectos fitogeográficos del Perú. Publ Inst Geogr Univ San Marcos I(B): 41-87.

FERREYRA R. 1983. The types of vegetation of the Peruvian coast. Anales Jard Bot Madrid 40: 241-256.

GALÁN DE MERA A, BALdEÓN S, BELTRÁN H, BENAVENTE M AND GÓMEZ J. 2004. Datos sobre la vegetación del centro del Perú. Acta Bot Malacitana 29: 89-115.

GALÁn DE MERA A, CÁCERES C AND GONZÁlez A. 2002b. Las comunidades con Cactáceas del Sur del Perú, II. 
Nueva asociación y alianza del Desierto Pacífico. Acta Bot Malacitana 27: 270-272.

GALÁN DE MERA A AND GÓMEZ CARRIÓN J. 2001. Las comunidades con Cactáceas del sur del Perú. Nuevos datos sobre la alianza Corryocaction brevistyli. Acta Bot Malacitana 26: 240-246.

GalÁn De Mera A AND Linares PereA E. 2012. La vegetación de la Región Arequipa (Perú). Arequipa: Universidad Nacional de San Agustín, 229 p.

Galán de Mera A, Linares Perea E, CAmpos de la CRuZ J, TRujillo Vera C, Villasante BenaVides F AND VICENTE ORELLANA JA. 2011. Novedades sobre la vegetación del Departamento de Arequipa (Perú). Arnaldoa 18(2): 125-144.

Galán de Mera A, Linares Perea E, Campos de la CRUZ J AND VICENTE ORELlANA JA. 2009. Nuevas observaciones sobre la vegetación del sur del Perú. Del Desierto Pacífico al Altiplano. Acta Bot Malacitana 34: 107-144

GAlÁN DE MERA A, RosA MV AND CÁCERES C. 2002a. Una aproximación sintaxonómica sobre la vegetación del Perú. Clases, órdenes y alianzas. Acta Bot Malacitana 27: 75-103.

GALÁN DE MERA A, SÁNCHEZ VEGA I AND LinARES PEREA E. 2013. Pisos bioclimáticos y vegetación en la Región de Cajamarca (Perú). Perspectiva 14(16): 119-129.

GALÁn DE MERA A AND ViCEnTE ORELlanA JA. 1996. Las comunidades con Corryocactus brevistylus del sur del Perú. Phytologia 80(1): 40-47.

Galán de Mera A, Vicente Orellana JA, Linares Perea E, CAmpos de la CRUZ J, TRujillo Vera C AND Villasante BenaVides F. 2012. Distribution patterns of cactus communities in the occidental slopes of the Peruvian Andes. Caldasia 34: 257-275.

GALÁN DE MERA A, ViCENTE ORELLANA JA, LUCAS GARCÍA JA AND PROBANZA LOBO A. 1997. Phytogeographical sectoring of the Peruvian coast. Global Ecol Biogeogr Lett 6: 349-367.

HAMMER Ø. 2014. PAST- Paleontological Statistics, ver. 3.04. Oslo: University of Oslo, $225 \mathrm{p}$.

HuNT D. 2006. The New Cactus Lexicon. Milborne Port: dh books, $899 \mathrm{p}$.

InSTITUTO DE GEOLOGÍA Y MINERÍA. 1975. Mapa Geológico del Perú. Escala 1: 1.000.000. Lima: Ministerio de Energía y Minas.

JØRGENSEN PM AND LEÓN-YÁÑEZ S. 1999. Catalogue of the Vascular Plants of Ecuador. St. Louis: Missouri Botanical Garden, $1181 \mathrm{p}$.

LINARES-PALOMINO R. 2004a. Los bosques tropicales estacionalmente secos: I. El concepto de bosques secos en el Perú. Arnaldoa 11(1): 85-102.

LINARES-PALOMINO R. 2004b. Los bosques tropicales estacionalmente secos: II. Fitogeografía y composición florística. Arnaldoa 11(1): 103-138.
LINARES-PALOMINO R, PENNINGTON RT AND BRIDGEWATER S. 2003. The phytogeography of the seasonally dry tropical forests in Equatorial Pacific South America. Candollea 58: 473-499.

LINARES-PALOMINO R AND PONCE ÁlVAREZ SI. 2005. Tree community patterns in seasonally dry tropical forests in the Cerros de Amotape Cordillera, Tumbes, Peru. Forest Ecol Manag 209: 261-272.

LiVERMORE R, NANKIVELl A, EAGLES G AND MORRIS P. 2005. Paleogene opening of Drake Passage. Earth and Planetary Sc Lett 236: 459-470.

LUEBERT F AND GAJARDO R. 2005. High Andean vegetation of Parinacota (northern Chile) and a synopsis of the southern Puna vegetation. Phytocoenologia 35: 79-128.

Montesinos DB, CLEEF AM AND SÝCORA KV. 2012. Andean shrublands of Moquegua, South Peru: Prepuna plant communities. Phytocoenologia 42: 29-55.

Ostolaza C. 2011. 101 Cactus del Perú. Lima: Ministerio del Ambiente, $253 \mathrm{p}$.

OSTOLAZA CN AND MISCHLES TC. 1984. Islaya omasensis. Bol Lima 6(32): 63-65.

PHILliPS O AND MiLLER JS. 2002. Global Patterns of Plant Diversity: Alwyn H. Gentry's Forest Transect Data Set. St. Louis: Missouri Botanical Garden Press, 319 p.

RANGEL JO. 2012. La vegetación de la región Caribe de Colombia: Composición florística y aspectos de la estructura. In: Rangel JO (Ed), Colombia Diversidad Biótica XII. Bogotá: Universidad Nacional de Colombia, p. 365-476.

RANGEL JO, LOWY PD, AGUILAR M AND GARZÓN A. 1997. Tipos de vegetación en Colombia. In: Rangel JO, Lowy PD and Aguilar M (Eds), Colombia Diversidad Biótica II. Bogotá: Universidad Nacional de Colombia, p. 89-381.

RAUH W. 1958. Beitrag zur Kenntnis der peruanischen Kakteenvegetation. Heidelberg: Springer, 542 p.

RITTER F. 1981. Kakteen in Südamerika. Spangenberg: Friedrich Ritter Selbstverlag, 1692 p.

RIVAS-MARTÍNEZ S AND RIVAS-SAENZ S. 1996-2009. Worldwide Bioclimatic Classification System. Available: http://www.globalbioclimatics.org. Accessed Jul 201415.

Ruiz A, CAVElier J, SANtos M AND Soriano PJ. 2002. Cacti in the Dry Formations of Colombia. In: Fleming $\mathrm{TH}$ and Valiente B (Eds), Cacti in the dry formations of Colombia. Tucson: Arizona University Press, p. 324-341.

SCHWARZER C, CÁCERES HuAMANí F, CANO A, LA TORRE MI AND WEIGEND M. 2010. 400 years for longdistance dispersal and divergence in the northern Atacama desert- Insights from the Huaynaputina pumice slopes of Moquegua, Peru. J Arid Environ 74: 1540-1551.

SVENSON HK. 1946. Vegetation of the coast of Ecuador and Peru and its relation to the Galapagos Islands. I. Geographical relations of the flora. Amer J Bot 33(6): $394-$ 426. 
THE PLANT LIST. 2013. Available: http://www.theplantlist. org/. Accessed Sep 201415.

Weber HE, MORAVEC J AND Theurillat JP. 2000. International Code of Phytosociological Nomenclature. $3^{\text {rd }}$ ed., J Veg Sci 11: 739-768.

WeBerbauer A. 1945. El mundo vegetal de los Andes Peruanos (Estudio fitogeográfico). Lima: Ministerio de Agricultura, $776 \mathrm{p}$.

WEIGEND M. 2002. Observations on the Biogeography of the Amotape-Huancabamba Zone in Northern Peru. Bot Rev 68(1): 38-54.

WEIGEND M. 2004. Additional observations on the biogeography of the Amotape-Huancabamba zone in Northern Peru: Defining the South Eastern limits. Rev Peru Biol 11(2): 127-134.

WHITTAKER R. 1972. Evolution and measurement of species diversity. Taxon 21: 213-251.

\section{SUPPLEMENTARY MATERIAL}

TABLE SII - Synthetic table made up with all the plots studied.

TABLE SIII - Table with the new associations described and their higher units.

\section{APPENDICES}

APPENDIX I: REFERENCES OF COMMUNITY NUMBERS OF THE TABLE SII

1. Diplopterydo leiocarpae-Acacietum macracanthae (authors, Table SIII, plots 28-31). 2. Diplopterydo leiocarpae-Acacietum macracanthae clusietosum pavonii (authors, Table SIII, plots 39-43). 3. Diplopterydo leiocarpae-Acacietum macracanthae (authors, Table SIII, plots 32-34). 4. Diplopterydo leiocarpae-Acacietum macracanthae flourensietosum cajabambensis (authors, Table SIII, plots 35-38). 5. Crotono ruiziani-Acacietum macracanthae (authors, Table SIII, plots 13-15). 6. Loxopterygio huasanginis-Neoraimondietum arequipensis (authors, Table SIII, plots 7-12). 7. Cercidio praecocis-Prosopidetum pallidae (Galán deMera etal.2002b,tab.2, plots 1-9).8. Haageocereo limensis-Neoraimondietum arequipensis (Galán de Mera et al. 2002a, tab. 3, plots 1-8). 9. Armatocereo balsasensis-Cercidietum praecocis (authors, Table SIII, plots 16-27). 10. Haageocereo versicoloris-
Armatocereetum proceri (authors, Table SIII, plots 1-6). 11. Haageocereo limensis-Neoraimondietum arequipensis (Galán de Mera et al. 2004, tab. 6, plots 1-4). 12. Haageocereo limensis-Neoraimondietum arequipensis plucheetosum chingoyonis (Galán de Mera et al. 2004, tab. 6, plot 5). 13. Haageocereo limensis-Neoraimondietum arequipensis puyetosum ferrugineae (Galán de Mera et al. 2004, tab. 6, plots 6 and 7). 14. Neoporterio islayensis-Neoraimondietum arequipensis (Galán de Mera et al. 2002a, tab. 1, plots 1-6). 15. Weberbauerocereo rauhii-Browningietum candelaris (Galán de Mera et al. 2009, tab. 11, plots 1-5). 16. Weberbauerocereo weberbaueri-Browningietum candelaris (Galán de Mera and Linares Perea 2012, tab. 17, plot 8 and 9). 17. Neoraimondio arequipensis-Browningietum viridis (Galán de Mera et al. 2011, tab. 2, plots 1-9). 18. Armatocereo riomajensis-Neoraimondietum arequipensis (Galán de Mera et al. 2011, tab. 2, plots 10 and 11. 19. Weberbauerocereo rauhiiBrowningietum candelaris larreetosum divaricatae (Galán de Mera et al. 2011, tab. 2, plots 12 and 13). 20. Weberbauerocereo rauhii-Corryocactetum brevistyli (Galán de Mera et al. 2009, tab. 12, plots 1-5). 21. Weberbauerocereo rauhiiCorryocactetum brevistyli crotonetosum ruiziani (Galán de Mera et al. 2009, tab. 12, plots 6 and 7). 22. Weberbauerocereo weberbaueri-Corryocactetum brevistyli (Galán de Mera and Gómez Carrión 2001, tab. 2, plots 1-7). 23. Balbisio weberbaueri-Ambrosietum artemisioidis (Galán de Mera et al. 2011, tab. 4, plots 1-4). 24. Armatocereo riomajensis-Euphorbietum apurimacensis (Galán de Mera et al. 2009, tab. 13, plots 1-7). 25. Grindelio bergii-Corryocactetum puquiensis (Galán de Mera and Gómez Carrión 2001, tab. 3, plots 1-4). 26. Weberbauerocereo torataensis-Corryocactetum brevistyli (Galán de Mera et al. 2009, tab. 12, plots 8 and 9). 27. Corryocacto aurei-Browningietum candelaris (Galán de Mera and Vicente Orellana 1996, tab. 2, plots 1-8). 28. Oreocereo tacnaensisCorryocactetum brevistyli (Galán de Mera and 
Vicente Orellana 1996, tab. 2, plots 9 and 10). 29. Echinopsio chalaensis-Randietum armatae (Galán de Mera et al. 2009, tab. 3, plots 1-4). 30. Caesalpinia spinosa plant community (Galán de Mera et al. 2009, tab. 3, plots 5-7). 31. Caesalpinio spinosae-Myrcianthetum ferreyrae (Galán de Mera et al. 2009, tab. 4, plots 1-9). 32. Anredero diffusaeDiplostephietum meyenii (Montesinos et al. 2012, tab. 4, plots 30-41).

APPENDIX II: LOCALITIES OF THE PLOTS OF THE TABLE
SIII

1-6- Ancash, Chamana (1- 18L 0218561-8866860, 2- 18L 0218561-8866860, 3- 18L 02182768866442, 4- 18L 0218276-8866442, 5- 18L 0216710-8862156, 6- 18L 0216710-8862156), 7-12- Cajamarca, Tembladera (7- 17M 07058139198832, 8- 17M 0705813-9198832, 9- 17M 0712341-9197226, 10- 17M 0712341-9197226, 11- 17M 0719716-9205886, 12- 17M 07197169205886), 13-15- Cajamarca, Magdalena (13-17M 0755789-9198704, 14- 17M 0755789-9198704,
15- 17M 0755789-9198704), 16-21- Cajamarca, Corral Quemado (16- 17M 0755321-9363707, 17- 17M 0755351-9363723, 18- 17M 07554119362946, 19- 17M 0755321-9362300, 20- 17M 0755423-9363054, 21- 17M 0755371-9361692), 22-26- Cajamarca, Chamaya (22- 17M 07553339361688, 23-17M 0755333-9361688, 24- 17M 0751915-9359574), 25- 17M 0751915-9359574, 26- 17M 0751857-9358444), 27- Cajamarca, entre Chamaya y Jaén (17M 0748509-9354658), 28-30- Cajamarca, Puente Crisnejas (28- 17M 0817143-9171706), 29- 17M 0817515-9171654, 30- 17M 0817526-9171594), 31-38- Cajamarca, San Marcos (31- 17M 0818838-9176016, 32- 17M 0819841-9177512, 33-17M 0819841-9177512, 34- 17M 0819663-9177160, 35- 17M 08178229178416, 36- 17M 0817822-9178416, 37- 17M 0810269-9190694, 38- 17M 0810269-9190694), 39-43- Cajamarca, río de las Yangas (39- 17M 0811865-9250066, 40- 17M 0812175-9249430, 41- 17M 0811894-9249428, 42- 17M 08120829248978, 43- 17M 0812879-9247668). 